\title{
PHENOTYPIC EXPRESSION IN THE DEVELOPING MURINE ENTERIC NERVOUS SYSTEM ${ }^{1}$
}

\author{
TAUBE P. ROTHMAN ${ }^{2}$ AND MICHAEL D. GERSHON \\ Department of Anatomy and Cell Biology, Columbia University, College of Physicians and Surgeons, \\ New York, New York, 10032
}

Received July 13, 1981; Revised November 4, I981; Accepted November 9, 1981

\begin{abstract}
The development of the enteric nervous system was examined in fetal mice. Synthesis of $\left[{ }^{3} \mathrm{H}\right]$ acetylcholine $\left(\left[{ }^{3} \mathrm{H}\right] \mathrm{ACh}\right)$ from $\left[{ }^{3} \mathrm{H}\right]$ choline and acetylcholinesterase histochemistry were used as phenotypic markers for cholinergic neurons, while the radioautographic detection of the specific uptake of $\left[{ }^{3} \mathrm{H}\right]$ serotonin $\left(5-\left[{ }^{3} \mathrm{H}\right] \mathrm{HT}\right)$ and immunocytochemical staining with antiserum to $5-\mathrm{HT}$ marked serotonergic neurons. The gut also was examined by light and electron microscopy. Development of the gut was studied in situ and in explants grown in organotypic tissue culture. Neurons were first detected morphologically in the foregut on embryonic day 12 (E12). Synthesis of $\left[{ }^{3} \mathrm{H}\right] \mathrm{ACh}$ was detectable on days E10 to E12 but increased markedly between days E13 and E14. Uptake and radioautographic labeling by $5-\left[{ }^{3} \mathrm{H}\right] \mathrm{HT}$ was seen first in the foregut on day $\mathrm{E} 12$, in the colon on day E13, and in the terminal colon on day E14. Gut explanted from both distal and proximal bowel prior to the time when neurons could be detected (days E9 to E11) nevertheless formed neurons in culture. These cultures of early explants displayed markers for both cholinergic and serotonergic neurons. Enhanced development of both cholinergic and serotonergic neurons was found in cultures explanted at day E11 over that found in cultures explanted on days E9 or E10. The evidence presented indicates (1) that enteric neurons develop from nonrecognizable precursors, (2) that the proximodistal gradient in neuronal phenotypic expression probably is not related to a proximodistal migration of precursor cells down the gut, (3) that the colonization of the bowel by neuronal precursors may be a prolonged process continuing from day $\mathbf{E} 9$ at least through day E11, (4) that the first pool of neuronal primordia to colonize the developing bowel can produce both cholinergic and serotonergic neurons. It is proposed that a sequential interaction of a long retained pool of dividing precursor cells with a fetal enteric microenvironment that changes as a function of time during ontogeny may be involved in producing the phenotypic diversity that characterizes the enteric nervous system.
\end{abstract}

The mature enteric nervous system contains a large and diverse population of neurons (Gershon, 1981). The small intestine is populated by a number of neurons that approximates that of the spinal cord (Furness and Costa, 1980) and, if neuronal phenotype is defined by neuro-

\footnotetext{
This work was supported by National Science Foundation Grant BNS-7911640, National Institutes of Health Grant NS 15547, and March of Dimes Grants 5-164 and 1-747. We wish to thank Dr. H. W. M. Steinbusch and Dr. J. Lauder for providing the antiserum to serotonin. We also want to thank Dr. Cheryl F. Dreyfus for her assistance in setting up the method of organotypic culture, Ms. Diane Sherman for excellent electron microscopy, and Ms. Linda Siconolfi and Mrs. Helen Mantulin for technical assistance.

2 To whom correspondence should be addressed at Department of Anatomy and Cell Biology, College of Physicians and Surgeons, Columbia University, 630 West 168th Street, New York, NY 10032.
}

transmitter or neuromodulator content, at least 10 different phenotypes characterize intrinsic enteric neurons (Furness and Costa, 1980; Gershon, 1981). Factors responsible for generating this large neuronal pool and its diversity of phenotypic expression are unknown. The microenvironment recently has been shown to play an important role in determining the transmitter choice of developing neurons both in vitro (Patterson, 1978; Bunge et al., 1978) and in vivo (LeDouarin, 1980; Landis and Keefe, 1980). It is thus possible that the microenvironment is similarly important in determining enteric neuronal phenotypes as well. Enteric neurons probably all are derived from precursor cells that colonize the gut following a migration from vagal and sacral levels of the neural crest (Andrew, 1971; Cantino, 1970; LeDouarin and Teillet, 1973; LeDouarin, 1980). Specifically, experiments were done to determine when and where these 
precursor cells begin to express gene products related to neurotransmitter mechanisms. Cholinergic and serotonergic neuronal properties were used as markers.

\section{Materials and Methods}

Experiments were done with CD-1 (Charles River) mice. Conception was dated from the appearance of a vaginal plug which was assigned the time embryonic day 0 (E0). For experiments not involving tissue culture, gravid females were killed by cervical dislocation and the fetuses were removed and dissected in Krebs solution as rapidly as possible. When tissue culture was done, dissection was performed under sterile conditions. In that case, a gravid mouse was anesthetized with ether and the body was soaked for $10 \mathrm{~min}$ in $80 \%$ ethanol prior to opening the abdomen and removing the uterus and fetuses.

Tissue culture. Explants were made of segments of caudal foregut and hindgut from embryos at age E9 and E10. At later ages, separate explants were made of terminal, mid, and proximal colon and sequential segments of small intestine ascending from the ileocolic junction to the stomach. Explants were no larger than $1 \times 1 \times 0.5$ $\mathrm{mm}$ and were maintained in culture on photoreconstituted collagen-coated coverslips in Maximow depression slide chambers as lying drop preparations (Bornstein, 1973; Cook and Peterson, 1974; Dreyfus et al., 1977a, b). Cultures were grown at $34.5^{\circ} \mathrm{C}$ and fed twice weekly. The nutrient medium (Bornstein, 1973) contained $33 \%$ human placental serum (heat inactivated at $56^{\circ} \mathrm{C}$ for $30 \mathrm{~min}$ ), $10 \%$ 9-day chick embryo extract, $50 \%$ Eagle's minimum essential medium plus glutamine with $7 \%$ Hank's balanced salt solution (single strength, Gibco No. 402; BSS), and $0.6 \%$ glucose. Cultures were grown for 2 weeks.

Synthesis of $\left[{ }^{3} \mathrm{H}\right]$ acetylcholine $\left.\left({ }^{3} \mathrm{H}\right] \mathrm{ACh}\right)$ from $\left[{ }^{3} \mathrm{H}\right]$ choline. Segments of fetal gut (days E11 to E17) or organotypic tissue cultures (explanted at days E10, E11, E12, and E14 and grown for 2 weeks) were studied. Intact tissues were equilibrated for 15 to $30 \mathrm{~min}$ in $3.0 \mathrm{ml}$ of Krebs solution containing physostigmine $(0.1 \mathrm{~mm})$ at $37^{\circ} \mathrm{C}$ prior to beginning the assay (Pert and Snyder, $1974)$ by the addition of $\left[{ }^{3} \mathrm{H}\right]$ choline $(80 \mathrm{Ci} / \mathrm{mmol}$; New England Nuclear Corp). Incubation was continued in the presence of $\left[{ }^{3} \mathrm{H}\right]$ choline $(1.0 \mu \mathrm{M})$ for $20 \mathrm{~min}$ and was stopped by the addition of $8.0 \mathrm{ml}$ of iced Krebs solution containing $1.5 \mu \mathrm{M}$ ACh, $1.5 \mu \mathrm{M}$ choline, and $0.1 \mathrm{mM}$ physostigmine. Fetal tissues then were washed four times for at least $15 \mathrm{sec}$ in the same solution and then homogenized in 0.5 to $1.0 \mathrm{ml}$ of formic acid:acetone $(15: 85)$. Extraction continued for 24 to $40 \mathrm{hr}$. Following centrifugation, the supernatant was evaporated to dryness in vacuo (Savant Instruments centrifugal dryer). The residue was dissolved in $0.5 \mathrm{ml}$ of formic acid:acetone and aliquots of $20 \mu \mathrm{l}$ with added ACh and choline carriers (both $1 \mathrm{mg} / \mathrm{ml}$ ) were streaked onto paper (Whatman No. 1) for high voltage electrophoresis. Choline and ACh were separated electrophoretically using a pyridine/acetate buffer at $\mathrm{pH} 4.7$; a current of $100 \mathrm{~mA}$ was passed for $140 \mathrm{~min}$ at $4^{\circ} \mathrm{C}$. ACh and choline were visualized on the paper with $I_{2}$ vapor. The resulting spots and the area in between were cut out and eluted with $2 \mathrm{ml}$ of distilled water, after which, $15 \mathrm{ml}$ of liquid scintillation cocktail
(Aquasol, New England Nuclear Corp.) was added for the determination of radioactivity. Data were expressed as femtomoles of $\left[{ }^{3} \mathrm{H}\right] \mathrm{ACh}$ synthesized per segment and as a ratio of $\left[{ }^{3} \mathrm{H}\right] \mathrm{ACh}$ to $\left[{ }^{3} \mathrm{H}\right]$ choline content. Cultures were treated similarly to intact fetal gut except that $\left[{ }^{3} \mathrm{H}\right]$ choline and physostigmine were added to tissue culture medium instead of to Krebs solution, at least 10 cultures were pooled for each assay, and results were expressed as femtomoles of $\left[{ }^{3} \mathrm{H}\right] \mathrm{ACh}$ synthesized per culture.

Uptake of $5-\left[{ }^{3} H\right]$ hydroxytryptamine $\left.\left(5-{ }^{3} H\right] H T\right)$. The uptake of $5-\left[{ }^{3} \mathrm{H}\right] \mathrm{HT}$ was used as a marker for the detection of serotonergic neurites (Gershon and Altman, 1971; Gershon et al., 1976; Rothman et al., 1976). Segments of fetal gut were incubated with the monoamine oxidase inhibitor, nialamide $(12.5 \mu \mathrm{M})$, at $37^{\circ} \mathrm{C}$ for $\left.15 \mathrm{~min} .5-{ }^{3} \mathrm{H}\right]$ HT ( 0.5 to $0.9 \mu \mathrm{M})$ was added and incubation was continued for an additional $45 \mathrm{~min}$. Incubation was stopped by transferring tissues to a hypertonic glutaraldehyde fixative solution and $5-\left[{ }^{3} \mathrm{H}\right] \mathrm{HT}$ was demonstrated by radioautography as described previously (Rothman et al., 1976; see below). As a control, incubation was done in the presence of the 5-HT uptake inhibitor, fluoxetine (10 $\mu \mathrm{M})$ (Wong et al., 1974; Gershon and Jonakait, 1979). Noradrenergic nerves of the gut nonspecifically take up 5-HT when 5-HT is present at high concentrations (Drakontides and Gershon, 1972); however, the $K_{m}$ for the uptake of 5-HT by noradrenergic axons is about $100 \mu \mathrm{M}$ (Thoa et al., 1969) and the noradrenergic innervation invades the developing gut long after the serotonergic innervation has been established (Rothman et al., 1976; Gintzler et al., 1980). Nonspecific uptake of $5-\left[{ }^{3} \mathrm{H}\right] \mathrm{HT}$ by noradrenergic nerves thus is not a problem with fetal tissues that lack this innervation. Radioautography, moreover, preserves only $5-\left[{ }^{3} \mathrm{H}\right] \mathrm{HT}$; radioactive metabolites of 5-HT wash out of tissues (Gershon and Ross, 1966). The uptake of 5 -[ $\left[{ }^{3}\right.$ II]IIT by organotypic tissue cultures was examined similarly except that nialamide and $5-\left[{ }^{3} \mathrm{H}\right] \mathrm{HT}$ were added to tissue culture medium and cultures were washed for $20 \mathrm{~min}$ in BSS prior to fixation.

Histological procedures. For electron microscopy, when radioautography was not done, small pieces of fetal tissue or whole cultures were fixed by immersion in a solution containing $0.5 \%$ acrolein, $2 \%$ glutaraldehyde, $2 \%$ formaldehyde (prepared from paraformaldehyde), and $0.5 \%$ dimethyl sulfoxide in $0.1 \mathrm{M}$ sodium cacodylate buffer with $0.01 \% \mathrm{CaCl}_{2}$. Tissues were postfixed in $1 \% \mathrm{OsO}_{4}$, rapidly dehydrated in ethanol, cleared in propylene oxide, and embedded in epoxy resin (Epon 812). All tissues were stained en bloc with aqueous uranyl acetate prior to dehydration.

For light microscopic radioautography, semithin (1$\mu \mathrm{m})$ sections were placed on slides that were coated with chromium alum gelatin. Ilford L4 photographic emulsion was diluted 1:1 with distilled water and applied to the slides by dipping. Slides were exposed for 7 to 21 days in light-tight boxes containing a drying agent (Drierite) at $4^{\circ} \mathrm{C}$. Slides were developed with D19 (Kodak) fixed, dried, and stained with toluidine blue (Rothman et al., 1976). Electron microscopic radioautography was done by the flat substrate method (Kopriwa, 1975). Silver sections were placed on collodion-coated glass slides. The slides then were coated with carbon and layered with 
Ilford L4 emulsion diluted 1:5 so as to produce a purple interference color. Sections were exposed at room temperature under an atmosphere of dry $\mathrm{CO}_{2}$. Radioautographs were developed with Microdol-X (Kodak) for 3 min. The collodion layer carrying the sections was floated off the glass slides and the sections were picked up on 200 mesh copper grids. If difficulty was encountered in floating off the collodion layers carrying the sections, a drop of $\mathrm{HF}$ was applied to a score made in the collodion film. Collodion was removed with alcohol and the sections were stained with uranyl acetate and lead citrate.

Acetylcholinesterase was demonstrated in cultures by a modification (Coughlin, 1975) of the method of ElBadawi and Schenk (1967). Essentially, washed cultures were fixed for $30 \mathrm{~min}$ in $10 \%$ buffered formalin, washed, and incubated for 1 to $4 \mathrm{hr}$ at $37^{\circ} \mathrm{C}$ in a medium containing: $1.73 \mathrm{~mm}$ acetylcholine iodide, $0.038 \mathrm{~N}$ sodium acetate, $0.002 \mathrm{~N}$ acetic acid, $5.0 \mathrm{~mm}$ sodium citrate, $3.0 \mathrm{~mm}$ cupric sulfate, $0.5 \mathrm{~mm}$ potassium ferricyanide, and $50 \mu \mathrm{M}$ tetraisopropylpyrophosphoramide (iso-OMPA, to inhibit
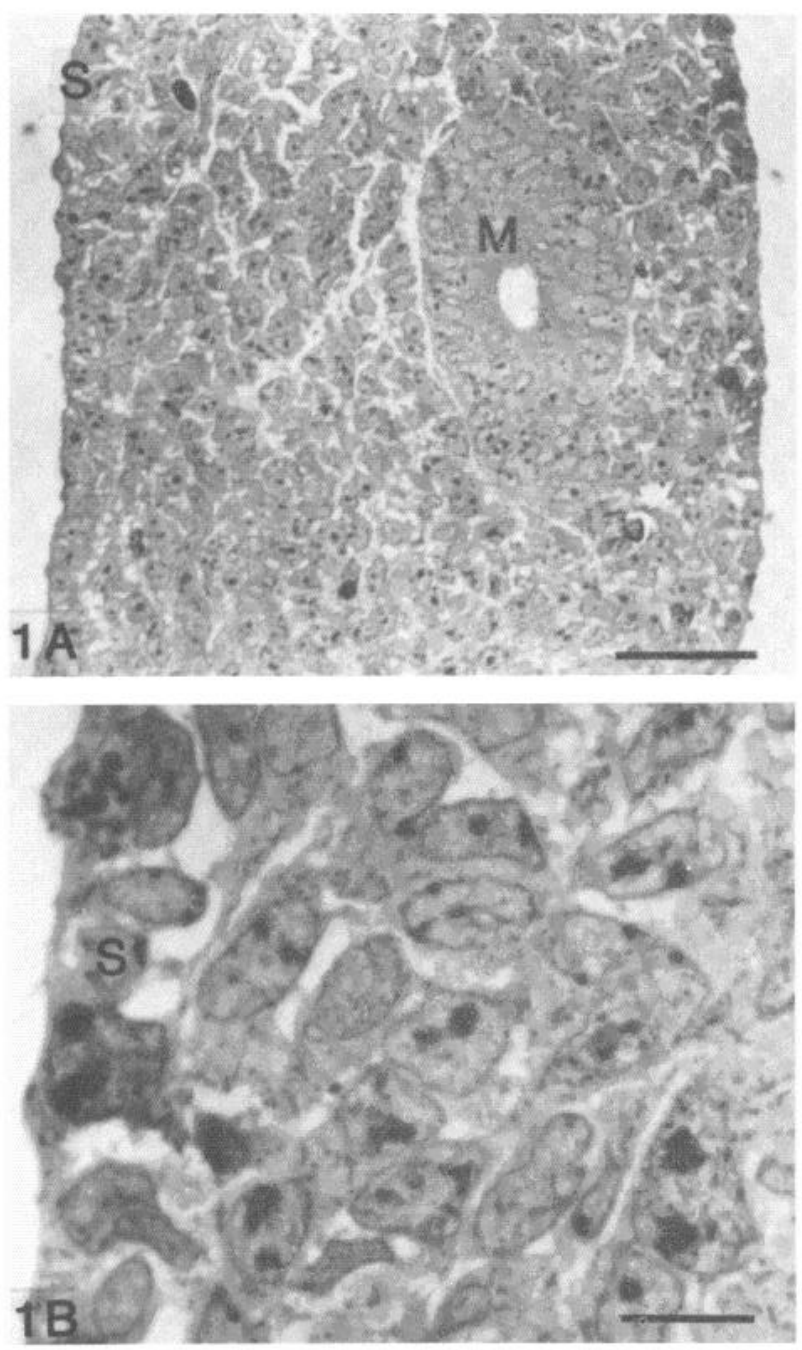

Figure 1. A, A toluidine blue-stained section of small intestine from a fetal mouse at day E11. $M$, Mucosa; $S$, serosa. Marker bar, $50 \mu \mathrm{m}$. B, A higher magnification picture of the section shown in $A$. The intestinal wall is shown near the serosa (S). No neural elements are visible. Marker bar, $10 \mu \mathrm{m}$. nonspecific esterases). Following incubation, cultures were washed, dehydrated, mounted in Permount, and examined as whole mounts using bright-field and Nomarski differential interference optics. In control studies, BW 284C51 (1,5-bis-[4-allyldimethylammonium phenyl] pentan-3-one dibromide, $0.2 \mathrm{~mm}$ ), an inhibitor of acetylcholinesterase (Tennyson and Brzin, 1970), was included in the reaction mixture.

Immunocytochemistry was used to locate 5-HT in fetal gut at day E18. Antibody was generously supplied by Dr. Harry Steinbusch (Department of Anatomy and Embryology, Catholic University Nijmegen, The Netherlands) and Drs. Jean Lauder and Peter Petrusz (The University of North Carolina, Chapel Hill, NC). Results were the same with both antisera. Fetal gut was fixed for $1 \mathrm{hr}$ in $0.1 \mathrm{~m}$ phosphate-buffered ( $\mathrm{pH} \mathrm{7.2)} 4 \%$ formaldehyde (prepared from paraformaldehyde) and postfixed overnight in buffered $4 \%$ formaldehyde containing picric acid. Tissues were washed for $30 \mathrm{~min}$ in phosphatebuffered saline (PBS), dehydrated, cleared, and embedded in paraffin. Sections were cut at $10 \mu \mathrm{m}$. Deparaffinized sections were incubated with the antisera to 5HT (diluted 1:1000 in PBS containing $0.1 \%$ Triton X100 ) for $32 \mathrm{hr}$ at $4^{\circ} \mathrm{C}$. Sections then were washed and incubated for $1 \mathrm{hr}$ with goat anti-rabbit IgG (diluted $1: 50)$ and finally for $2 \mathrm{hr}$ with the peroxidase-antiperoxidase complex (PAP; diluted 1:50). Peroxidase activity was demonstrated by incubation for 6 min with $0.01 \%$ $\mathrm{H}_{2} \mathrm{O}_{2}$ (30\% solution) and $0.013 \% 3,3^{\prime}$-diaminobenzidine (Sigma) in $0.1 \mathrm{~m}$ Tris-HCl buffer, $\mathrm{pH}$ 7.6. After a 10 -min wash in distilled water, the sections were dehydrated and mounted in Permount. In other experiments, fluoresceinlabeled goat anti-rabbit IgG (Cappel Laboratories, Inc.; diluted $1: 50$ ) was used to locate bound anti-5-HT anti-

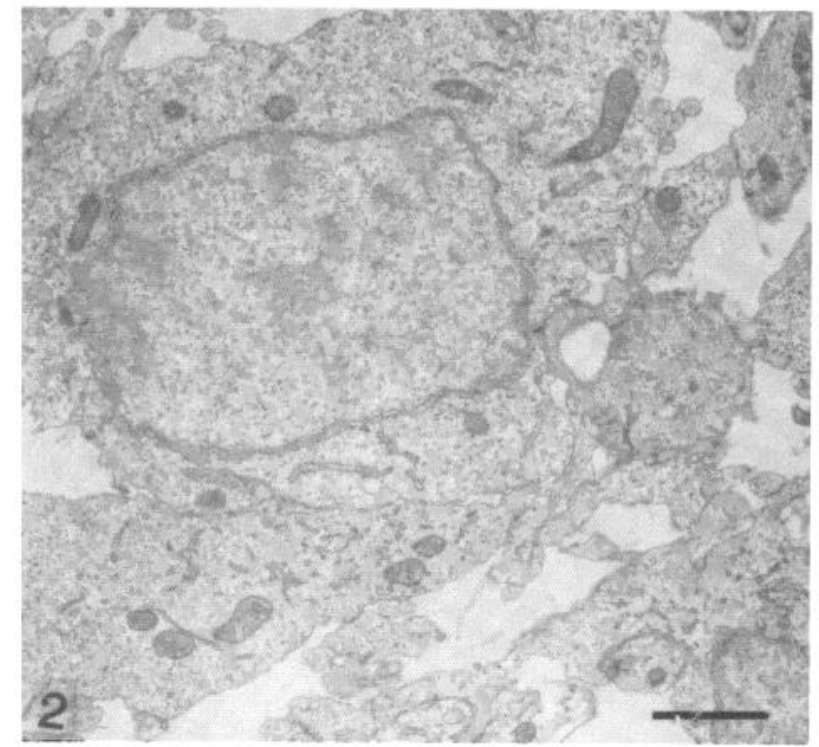

Figure 2. An electron micrograph of a portion of the mesenchyme of the small intestine of a fetal mouse removed at day E11. The primitive mesenchymal cells contain euchromatic nuclei and many free ribosomes in their cytoplasm. The cells extend long processes, but none appear neuritic (see Fig. 3) in structure. No neurotubules can be discerned. Marker bar, 2.0 $\mu \mathrm{m}$. 
body instead of the PAP technique. Similar results were obtained. Specificity of the antisera has been studied and published (Steinbusch and Verhofstad, 1979; Steinbusch et al., 1980). Essentially, the antibodies have a high affinity for 5-HT and a much lower affinity for 5-methoxytryptamine and dopamine, while affinity for norepinephrine or epinephrine is negligible. In the CNS, however, dopaminergic neurons do not react with the 5-HT antiserum. No staining was observed when antisera were absorbed with $5 \mathrm{~mm} 5$-HT. It is probable, therefore, that neurites demonstrated with the anti-5-HT antiserum are serotonergic.

\section{Results}

\section{In situ development}

Morphology. At days E9, E10, and E11, the mouse gut contains no cells recognizable as neurons (Figs. 1 and 2). The mucosal epithelium is stratified at these times. It is surrounded by a mesenchyme that shows no regional specializations. The mesenchyme, in turn, is enclosed within a simple cuboidal serosal epithelium. The earliest time that neural elements can be detected in the foregut is E12. At this time, neural islands appear in the outer gut mesenchyme. The neural islands can be recognized

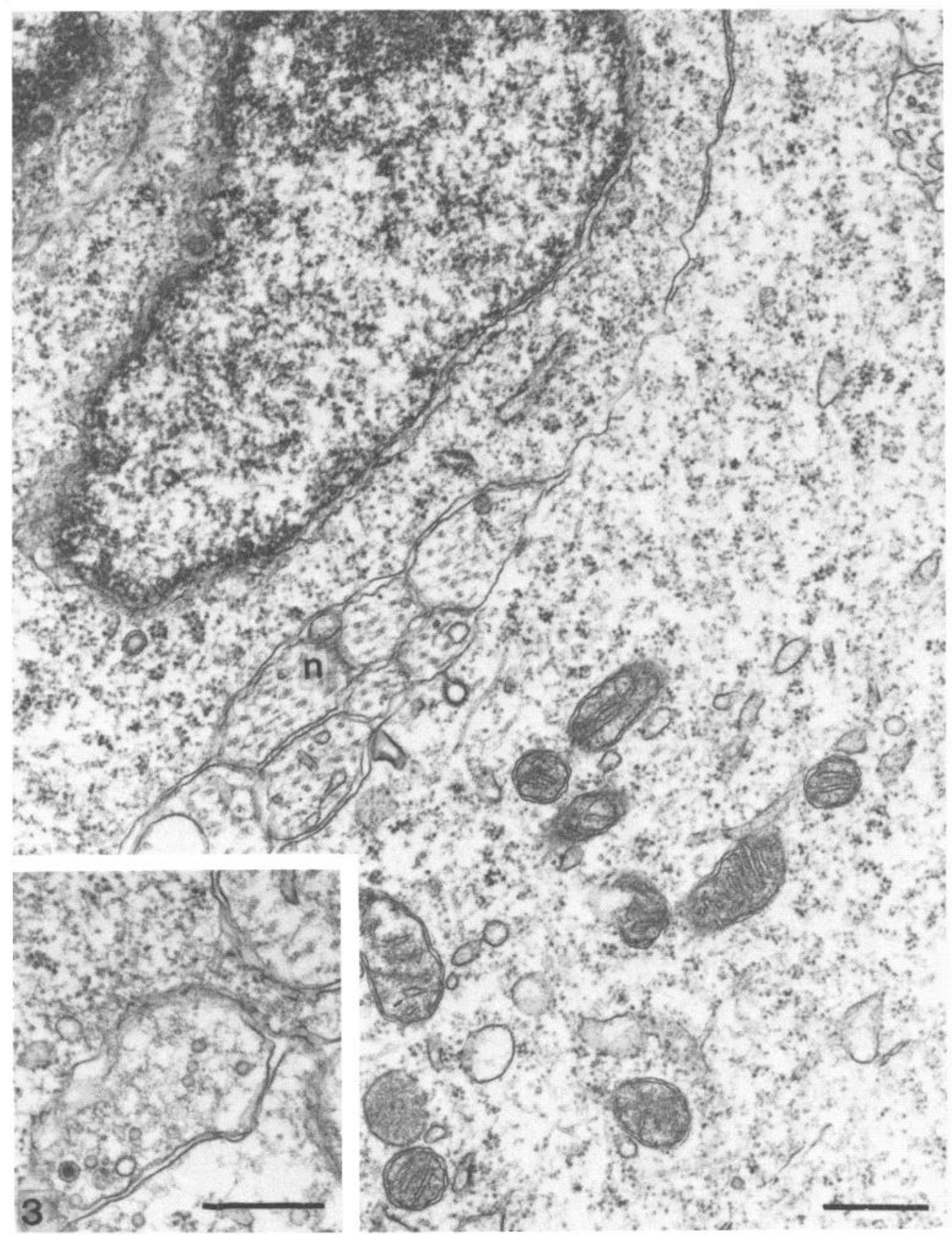

Figure 3. An electron micrograph of a section cut through a developing ganglion in the small intestine of a fetal mouse on day E12. Note the aggregation of neurites $(n)$ containing parallel neurotubules that help to identify the ganglion. The inset shows a varicose neuritic expansion containing vesicles, one of which has an electron-dense core. No pre- or postsynaptic membrane specializations can yet be found. Marker bars, $0.5 \mu \mathrm{m}$. 
electron microscopically by the presence within them of neuritic processes (Fig. 3 ). These processes constitute a primitive neuropil. The presumptive ganglion cells, however, even at day E12, remain immature and difficult to distinguish from the surrounding mesenchymal cells. Rough endoplasmic reticulum remains sparse and the cytoplasm of these presumptive neurons is filled with free polyribosomes. Rarely, varicose expansions of neurites can be distinguished in apposition to neuronal somata (Fig. 3, inset). These varicosities contain large granulated vesicles and some smaller vesicles, but synaptic membrane specializations are not in evidence.

Extensive neuritic maturation occurs on days E13 and E14. The neuropil expands on day E13 but still contains many growth cones (Fig. 4). These growth cones resemble those of CNS neurites (Tennyson, 1970). On day E14, the dense packing of axons that characterizes the mature myenteric plexus has developed (Fig. 5), growth cones are encountered less commonly, and the developing neurons show many dilated cisternae of rough endoplasmic reticulum. On day E14, as well, the circular muscle has formed and partitions the mesenchyme into inner (submucosal) and outer compartments (Fig. 6). The neural islands of the myenteric plexus remain external to the circular muscle layer. The submucosal plexus has not yet begun to develop. The longitudinal muscle becomes apparent on day E16, but the submucosal plexus remains difficult to discern even until day E18.

Biosynthesis of $\left[{ }^{3} \mathrm{H}\right] \mathrm{ACh}$. Fetal tissue was incubated with $\left[{ }^{3} \mathrm{H}\right]$ choline and the biosynthesis of $\left[{ }^{3} \mathrm{H}\right] \mathrm{ACh}$ was measured as a marker for cholinergic neuronal development. The biosynthesis of $\left[{ }^{3} \mathrm{H}\right] \mathrm{ACh}$ was found to be temperature dependent and antagonized by excess non-

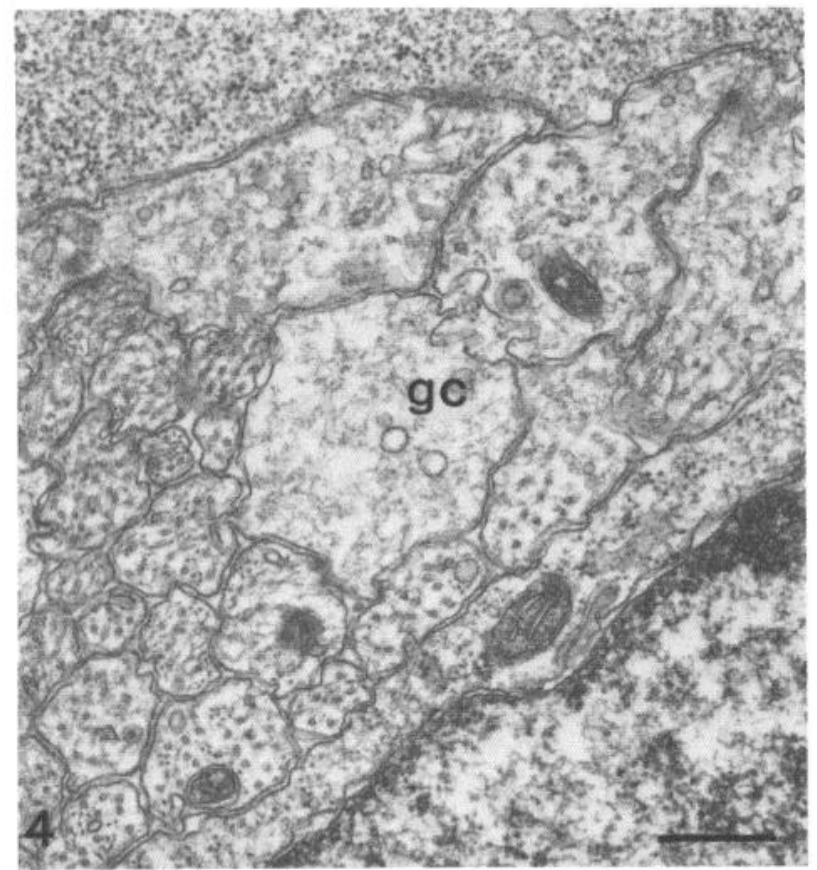

Figure 4. An electron micrograph of the neuropil of a developing ganglion in the small intestine of a fetal mouse on day E13. Many more neurites appear at this age than at day E12 (compare with Fig. 3). The primitive nature of the nervous system is still evident in the numerous growth cones $(g c)$ in the neuropil. Marker bar, $0.5 \mu \mathrm{m}$.

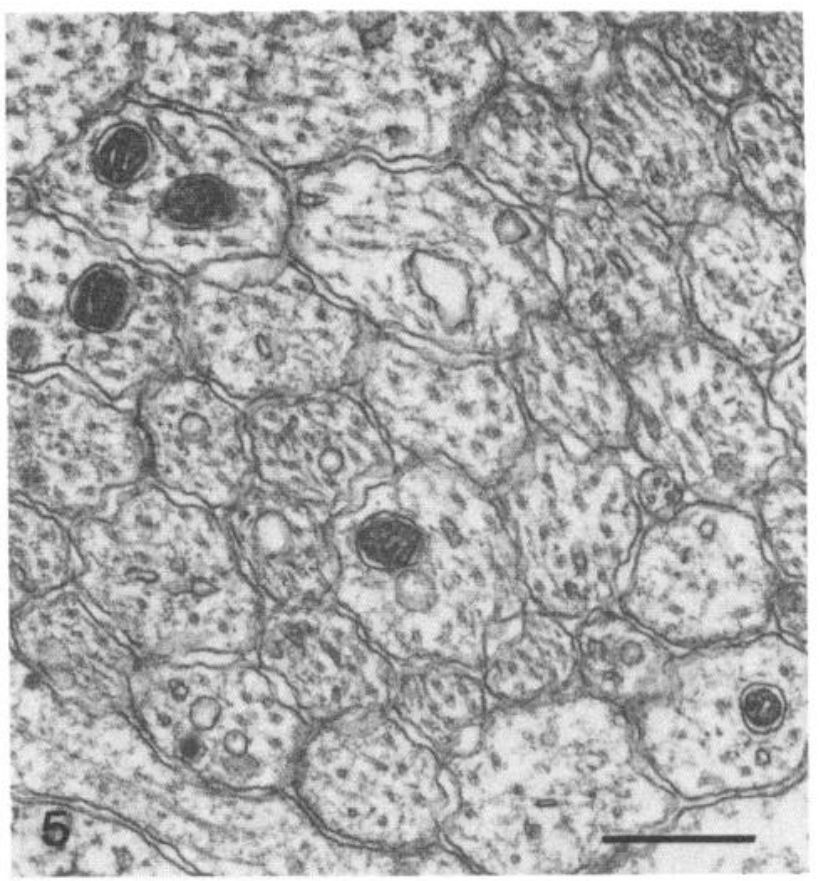

Figure 5. Electron micrograph showing the closely packed neuropil that characterizes the myenteric plexus at day E14. Note how neurites abut on one another. Marker bar, $0.5 \mu \mathrm{m}$.

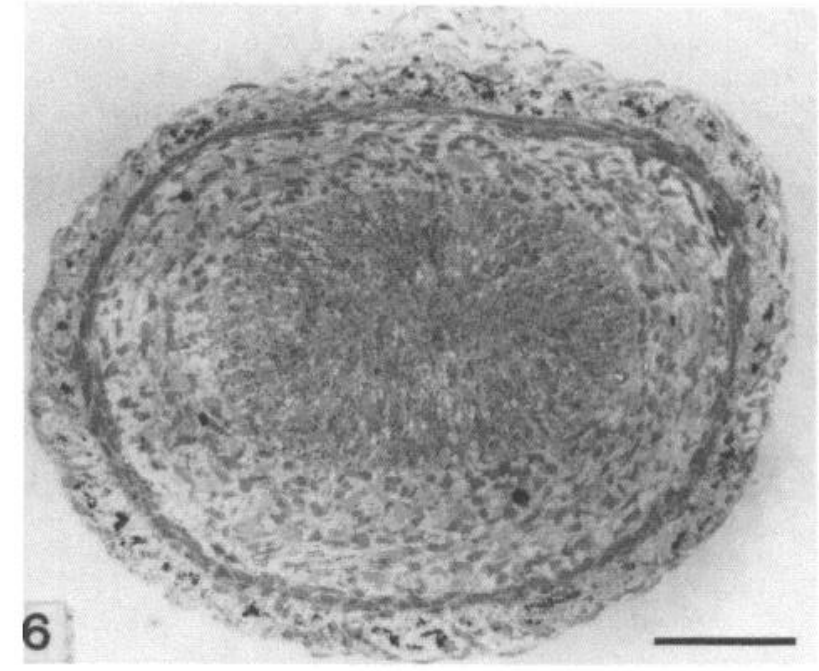

Figure 6. A semithin $(1.0-\mu \mathrm{m})$ section of the small intestine of a fetal mouse at day E14. The tissue has been incubated with $5-\left[{ }^{3} \mathrm{H}\right] \mathrm{HT}$ and subjected to radioautography. Note the partitioning of the mesenchyme of the intestinal wall into inner (submucosal) and outer compartments. The presence of neuritic islands in the outer compartment is made apparent by their radioautographic labeling (accumulations of black silver grains) by $5-\left[{ }^{3} \mathrm{H}\right] \mathrm{HT}$. The three labeled spots in the submucosa are over platelets in blood vessels. Like neurites, platelets take up $5-\left[{ }^{3} \mathrm{H}\right] \mathrm{HT}$. Marker bar, $50 \mu \mathrm{m}$.

radioactive choline as well as the choline uptake inhibitor, hemicholinium (Pert and Snyder, 1974; Haubrich and Chippendale, 1977) (Table I). It seems likely, therefore, that the biosynthesis of $\left[{ }^{3} \mathrm{H}\right] \mathrm{ACh}$ from $\left[{ }^{3} \mathrm{H}\right]$ choline by fetal gut is linked to and depends on the high affinity uptake of $\left[{ }^{3} \mathrm{H}\right]$ choline.

Some biosynthesis of $\left[{ }^{3} \mathrm{H}\right] \mathrm{ACh}$ from $\left[{ }^{3} \mathrm{H}\right]$ choline can 
be detected in the developing gut as early as day E11 (Fig. 7). The amount synthesized, however, remains low relative to the uptake of $\left[{ }^{3} \mathrm{H}\right]$ choline itself until day E13. Between days E13 and E14, coincidentally with the maturation of the myenteric plexus described above, the ratio of $\left[{ }^{3} \mathrm{H}\right] \mathrm{ACh}$ synthesized to $\left[{ }^{3} \mathrm{H}\right]$ choline taken up rises precipitously (Fig. 7). After day E14, this ratio remains relatively constant.

\section{Serotonergic neurites}

$5-\left[{ }^{3} \mathrm{H}\right] \mathrm{HT}$ is taken up by several constituents of the fetal gut. Platelets within the lumina of developing blood vessels concentrate the amine and become intensely labeled. Primitive mucosal epithelial cells also manifest a moderate uptake of $5-\left[{ }^{3} \mathrm{H}\right] \mathrm{HT}$. Specific neuronal uptake, however, cannot be detected by radioautography until day E12, when neurites in the developing islands of myenteric plexus of the presumptive duodenum take up the amine (Fig. $8 A$ ). Neuritic uptake of $5-\left[{ }^{3} \mathrm{H}\right] \mathrm{HT}$ at this and later ages is abolished by the 5-HT uptake inhibitor, fluoxetine (Fig. 9A). This specific uptake of $5-\left[{ }^{3} \mathrm{H}\right] \mathrm{HT}$ develops later than day E12 in more caudal regions of the gut. It reaches the proximal colon on day E13 and the terminal colon on day E14. Once uptake of $5-\left[{ }^{3} \mathrm{H}\right] \mathrm{HT}$ begins, it is a constant feature of the developing myenteric plexus (Figs. 6, 8, and 9B). As late as day E18, however, labeling remains predominantly confined to neurites; only a few perikarya of the myenteric plexus were found to be labeled. No elements of the submucosal plexus, deep muscle plexus, or intramucosal nerves were labeled with $5-\left[{ }^{3} \mathrm{H}\right] \mathrm{HT}$ at any age during fetal life. Uptake

TABLE I

Synthesis of $\left[{ }^{3} \mathrm{H}\right] \mathrm{ACh}$ by fetal mouse (E14) gut

The values shown are the means $\pm \mathrm{SE}$.

\begin{tabular}{ccrlr}
\hline Incubation Conditions & Small Intestine & $n$ & Colon & $n$ \\
\hline & fmol/gut & & fmol/gut & \\
$37^{\circ} \mathrm{C}$ & $58.4 \pm 5.2$ & 15 & $8.8 \pm 1.2^{a}$ & 15 \\
Hemicholinium $(10 \mu \mathrm{M})$ & $0.8 \pm 0.08^{b}$ & 8 & $0.3 \pm 0.1^{\mathrm{c}}$ & 8 \\
$4^{\circ} \mathrm{C}$ & 0.5 & 3 & 0.5 & 3 \\
Excess choline $(1 \mathrm{mM})$ & 0.2 & 3 & 0.5 & 3 \\
\hline
\end{tabular}

${ }^{a} p<0.001$ versus small intestine at $37^{\circ} \mathrm{C}$.

${ }^{b} p<0.001$ versus small intestine at $37^{\circ} \mathrm{C}$.

' $p<0.001$ versus colon at $37^{\circ} \mathrm{C}$.

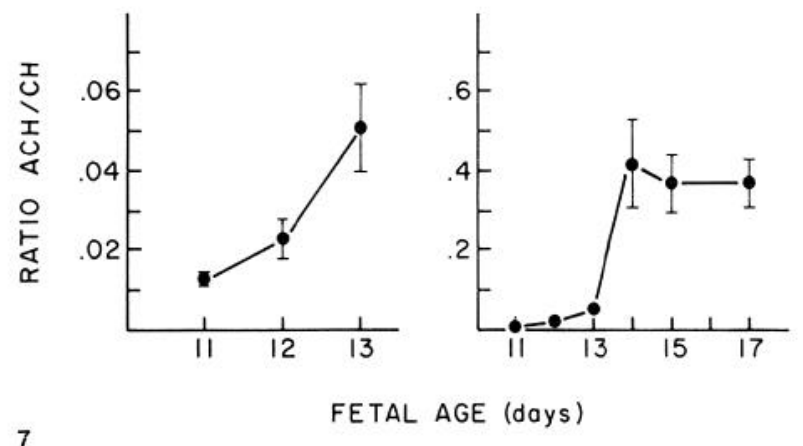

Figure 7. Synthesis of $\left[{ }^{3} \mathrm{H}\right] \mathrm{ACh}$ from $\left[{ }^{3} \mathrm{H}\right]$ choline by the fetal mouse gut. The ratio of $\left[{ }^{3} \mathrm{H}\right] \mathrm{ACh}$ to $\left[{ }^{3} \mathrm{H}\right]$ choline in the tissue is plotted as a function of fetal age. The graph at the left shows the ratio on a magnified scale at the earliest ages, when synthesis of $\left[{ }^{3} \mathrm{H}\right] \mathrm{ACh}$ can first be detected.
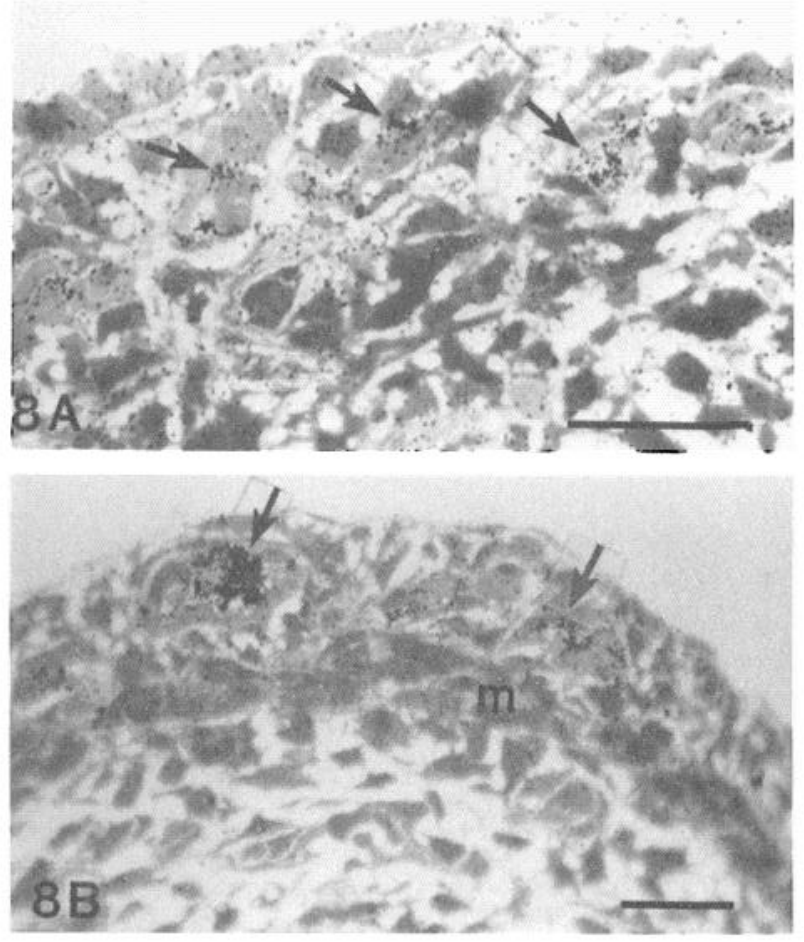

Figure 8. Radioautographs of the developing myenteric plexus of the small intestine of fetal mice at ages E12 $(A)$ and E13 $(B)$. The tissue was incubated with $5-\left[{ }^{3} \mathrm{H}\right] \mathrm{HT}$. The radioactive amine has been taken up by elements of the neuropil (arrows). Note the beginning of the condensation of the circular muscle layer $(m)$ at age E13 $(B)$. Neither the muscle nor the mesenchyme of the submucosa are labeled. Marker bars, 20 $\mu \mathrm{m}$.

of $5-\left[{ }^{3} \mathrm{H}\right] \mathrm{HT}$ persists in platelets throughout development; however, maturation of the mucosal epithelium is marked by a loss of its ability to take up the amine. As villi form, the epithelium ceases to become labeled by 5 $\left[{ }^{3} \mathrm{H}\right] \mathrm{HT}$.

At day E18, neurites of the myenteric plexus can be demonstrated with antisera to 5-HT (Fig. 10). No such neurites can be found when antisera are used that have been absorbed with 5-HT. As occurred when radioautography of material incubated with $5-\left[{ }^{3} \mathrm{H}\right] \mathrm{HT}$ was used to demonstrate serotonergic neurites, only neuritic processes were demonstrated by the antisera. Serotonergic neuronal perikarya have not yet been seen with the antisera in fetal mouse gut. No attempt, however, was made to amplify the concentration of 5 - $\mathrm{HT}$ in tissue pharmacologically nor to promote a buildup of the amine in cell bodies. Nevertheless, serotonergic neurites seem to have acquired the ability to synthesize and store endogenous 5-HT by day E18 as well as to take up the transmitter.

\section{In vitro development}

Explants removed as early as days E9, E10, and E11, prior to the development of recognizable neurons, nevertheless formed neurons in culture (Figs. 11 to 13). Neuronal precursor cells, therefore, must have been present in at least some regions of the fetal gut at the time of explantation on days E9, E10, and E11. These precursor 

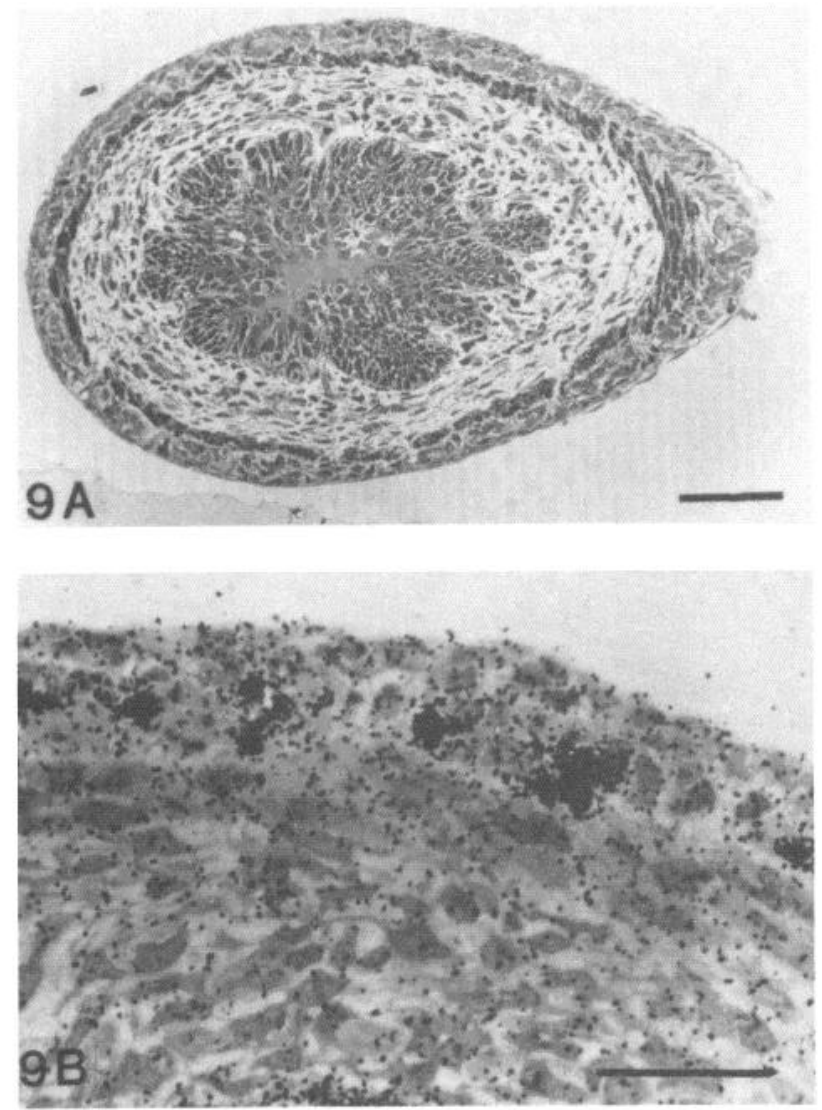

Figure 9. Radioautographs of small intestine from a fetal mouse at age E16. The tissue was incubated with $5-\left[{ }^{3} \mathrm{H}\right] \mathrm{HT}$ in the presence $(A)$ and absence $(B)$ of fluoxetine. Intensive labeling of the neuropil of the developing myenteric plexus is evident $(B)$. The uptake of $5-\left[{ }^{3} \mathrm{H}\right] \mathrm{HT}$ and radioautographic labeling is prevented by fluoxetine. Marker bars, $50 \mu \mathrm{m}(A)$ and $20 \mu \mathrm{m}(B)$.

cells, however, also must have been morphologically indistinguishable from the mesenchymal cells that surrounded them.

Explants removed from fetuses at day E11 differed in their further development in vitro from explants removed at days E9 and E10. In the first place, a greater number of E11 explants demonstrated acetylcholinesterase-containing neurons than did explants removed at days E9 and E10 (Table II). Secondly, at least some of the explants removed at day E11 (but never earlier) developed sheets of smooth muscle in two layers oriented appropriately perpendicular to one another. These cultures manifested extensive acetylcholinesterase-containing networks or plexuses of neurites (Fig. 11, C and $D$ ) and formed a myenteric plexus in relationship to the smooth muscle fibers (Fig. 13). Pooled explants removed at days E10, E11, or later all synthesized $\left[{ }^{3} \mathrm{H}\right] \mathrm{ACh}$ from $\left[{ }^{3} \mathrm{H}\right]$ choline (Table III).

Cultures removed on day E9 or afterward not only developed cholinergic neurons but also developed neurites that took up $5-\left[{ }^{3} \mathrm{H}\right] \mathrm{HT}$ (Figs. 12 and 13). In these cultures, uptake of $5-\left[{ }^{3} \mathrm{H}\right] \mathrm{HT}$ was confined mainly to neurites as was true of the labeling by $5-\left[{ }^{3} \mathrm{H}\right] \mathrm{HT}$ of the myenteric plexus in situ. Labeling was encountered less frequently in the cultures of gut explanted at days E9 or E10 than at E11 or later. Electron microscopic radioau-
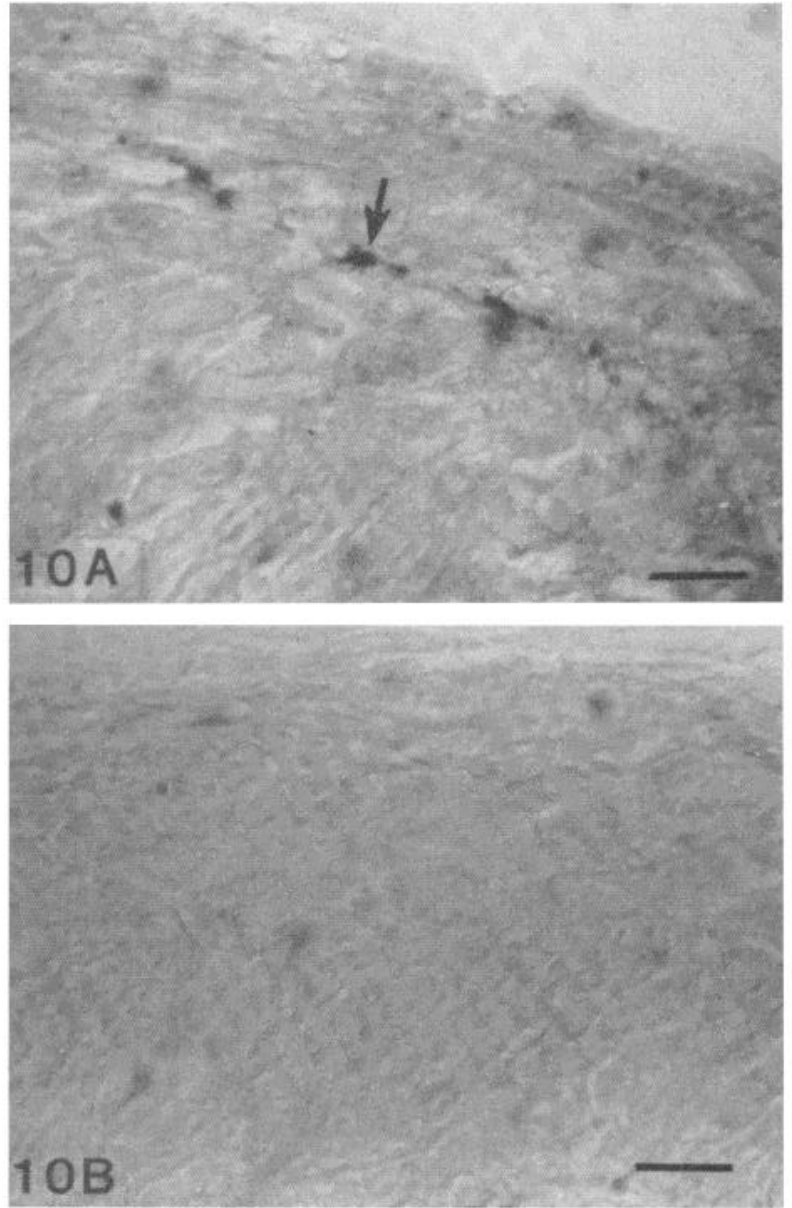

Figure 10. Thick sections of the small intestine of a fetal mouse exposed to anti-5-HT antiserum and the PAP technique for the immunocytochemical localization of 5-HT. The section shown in $A$ was exposed to the antiserum diluted 1:1000. The section shown in $B$ was exposed to the same antiserum that had been absorbed with 5-HT (5 mM). 5-HT-like immunoreactivity is seen in a varicose neurite projecting across the field in $A$ (arrow), but no immunoreactive neurites are found in tissue treated with antisera absorbed with 5-HT. Marker bars, $10 \mu \mathrm{m}$.

tography, in addition to confirming neuritic labeling in the E11 cultures, also permitted the identification of occasional cell bodies of neurons that were labeled by 5 $\left[{ }^{3} \mathrm{H}\right] \mathrm{HT}$ in the cultured myenteric plexus (Fig. 14). These labeled cells were quite primitive in their ultrastructure. They contained many free polyribosomes in their cytoplasm. They were all within the confines of the basal lamina that surrounded the myenteric plexus even in vitro, made contacts (without synaptic membrane modifications) with vesicle-containing axonal terminal varicosities, and remained separated by glial processes from the collagen-containing connective tissue around the plexus. Explants removed at days E9 or E10, therefore, can develop both cholinergic and serotonergic neurons in culture. The development of both types of neuron is enhanced, however, if explantation is done at day E11 or later.

\section{Discussion}

These studies have demonstrated that enteric neuronal development cannot be detected morphologically in the 

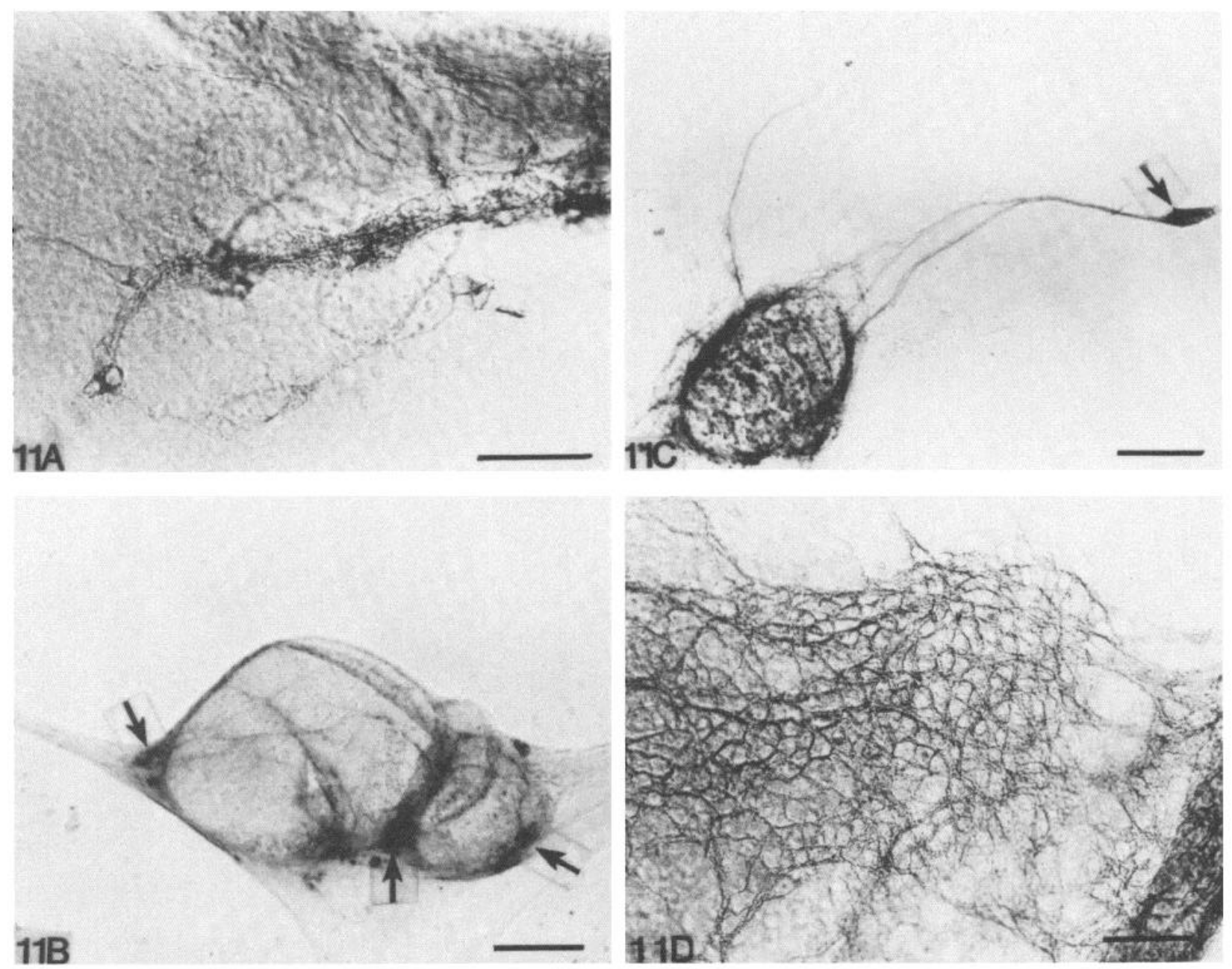

Figure 11. Explants of fetal mouse gut grown for 2 weeks in organotypic tissue culture and prepared as whole mounts for the demonstration of acetylcholinesterase activity. A, Tissue explanted at E9. Reactive neurites and cell bodies can be seen. Marker bar, $30 \mu \mathrm{m} . B$, Tissue explanted at E10. Bundles of reactive neurites extend from reactive ganglia (arrows) in the explant. Marker bar, $200 \mu \mathrm{m}$. C , Tissue explanted at E11. Dense reactive bundles of neurites surround the explant and connect it to a satellite ganglion (arrow) that has grown away from the main mass of tissue. Marker bar, $200 \mu \mathrm{m}$. $D$, A dense network of neurites that display acetylcholinesterase activity can be seen in this culture explanted at E11. Marker bar, $50 \mu \mathrm{m}$.

fetal mouse small or large intestines prior to day E12. There is a population of proliferating catecholaminergic cells in the bowel that appears transiently between days E9 and E11 (Teitelman et al., 1981); these cells, however, cannot be recognized as neuronal and they disappear (Cochard et al., 1978; Teitelman et al., 1978) before the enteric plexuses can be discerned. On day E12, developing neurons appear and resemble mesenchymal cells even in fine structure but can be distinguished from the surrounding mesenchyme by their aggregation into neuritic islands and by the formation of processes that constitute a primitive neuropil. Enteric neuronal development, therefore, occurs within the mesenchyme of the gut and precedes the partitioning of the mesenchyme by the developing circular muscle layer into inner (submucosal) and outer compartments. This pattern is similar to that which occurs in the developing guinea pig intestine (Gershon et al., 1981). Subsequent enteric development is marked by sequential changes in the microenvironment that the primitive gut presents to the developing neurons. Three important questions arise. Are neuronal precursor cells present in the developing gut prior to the appearance of recognizable elements of the myenteric plexus? Is the timing of the expression of the neuronal phenotype related to the timing of the arrival of precursors in different levels of the bowel? Does the cohort of neuronal primordia that initially invade the gut include precursors of only one of the neurotransmitter-defined phenotypes of enteric neuron or more of them?

The answer to the first of these questions clearly seems to be that the precursors of the enteric neurons colonize the gut long before enteric neurons acquire morphologically recognizable characteristics. When we explanted fetal gut prior to the appearance of morphoiogically recognizable neuritic islands and grew the explants for an extended period of time in organotypic tissue culture, neurons developed in the cultures. Certainly there can be no continued delivery of precursor cells from an extrinsic source to the fetal gut in culture; therefore, the precursors must have been present within the fetal gut even though these precursors could not be recognized at the time of original explantation. Since neurons devel- 


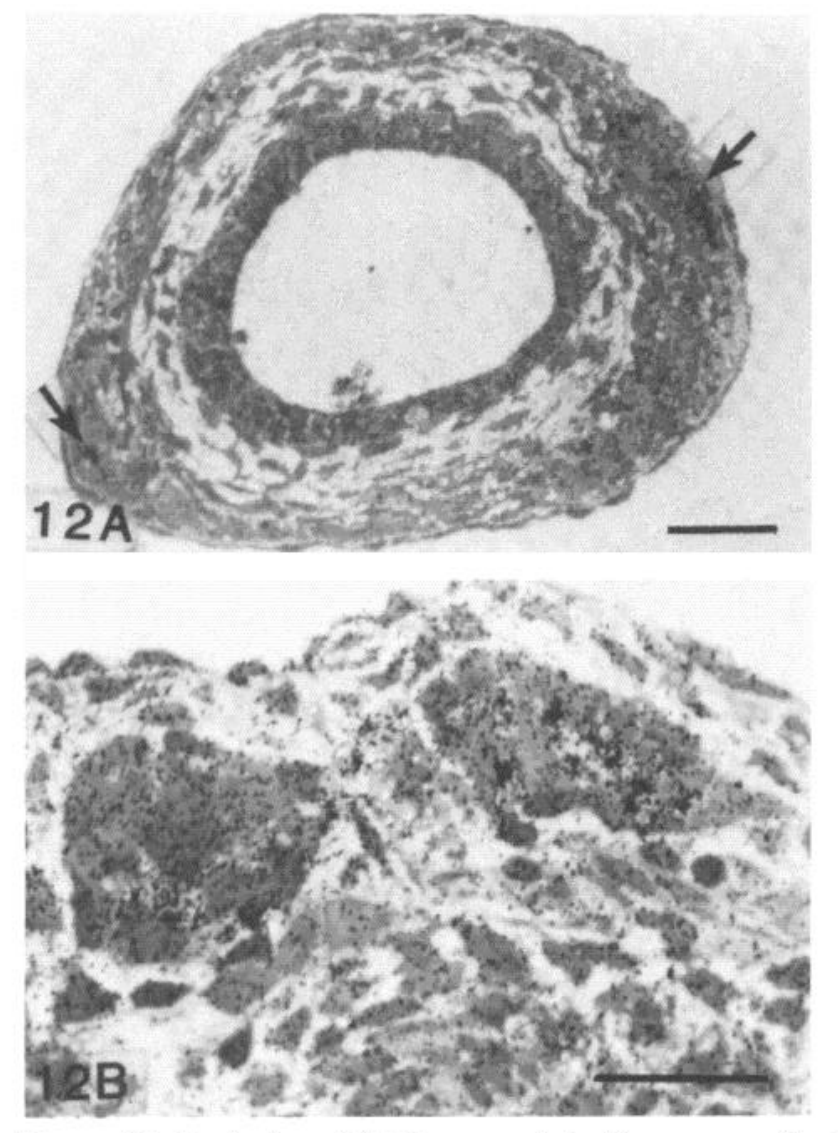

Figure 12. Explants of fetal mouse intestine grown for 2 weeks in organotypic tissue culture. The explants were removed at day E9. Cultures were incubated with $5-\left[{ }^{3} \mathrm{H}\right] \mathrm{HT}$ and then were fixed, embedded, sectioned at $1 \mu \mathrm{m}$, and prepared for radioautography. Labeled neurites can be found in ganglia (arrows) in the wall of the cultured gut. Marker bars, $30 \mu \mathrm{m}$ $(A)$ and $20 \mu \mathrm{m}(B)$.

oped in gut explanted into culture as early as day E9, at least some neuronal precursors must reach the primitive bowel by that time. Work done on developing avian gut, involving transplantation to the chorioallantoic membrane of chick embryo hosts, also supports the contention that unrecognizable precursor cells colonize the bowel and acquire their mature phenotype within the gut itself (Andrew, 1964; Allan and Newgreen, 1980; Gershon et al., 1980) and further indicates that the phenomenon is a general one, present in both birds and mammals. It has been claimed, however, in chicks that precursors do not invade intestinal segments more than $12 \mathrm{hr}$ prior to recognizable neuronal development (Allan and Newgreen, 1980). If so, it would seem from our experiments that neuronal primordia spend a much longer period in an undeveloped state (up to 3 days) in the murine bowel than they do in the gut of the chick.

The long interval between the arrival of precursors in the gut and the time when neuronal phenotypic expression becomes apparent makes it unlikely that the timing of neuronal appearance is related to the timing of arrival of precursors in various levels of the bowel. Expression of neuronal marker properties occurs in a proximodistal gradient down the gut (Webster, 1973). This has led to the proposal that neuronal precursors are all derived

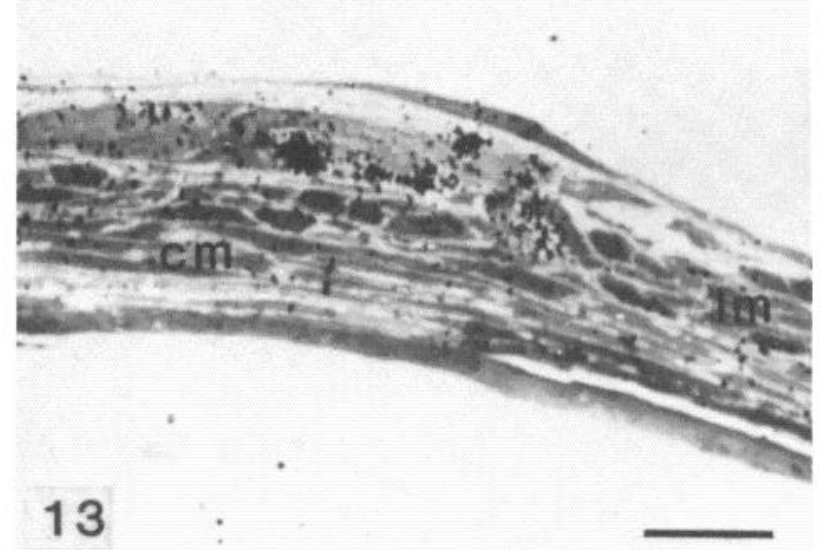

Figure 13. An explant of fetal mouse intestine that was removed from the animal at E11 and grown for 2 weeks in organotypic tissue culture. Cultures were incubated with $5-\left[{ }^{3} \mathrm{H}\right]$ HT and prepared for radioautography. Two perpendicular layers of smooth muscle $\left(\mathrm{lm}\right.$ and $\mathrm{cm}$ ) are present and $5-\left[{ }^{3} \mathrm{H}\right] \mathrm{HT}$ has labeled neurites in an enteric ganglion. (Compare with Fig. 12.) Marker bar, $10 \mu \mathrm{m}$.

TABLE II

Proportion of cultures containing neurons that demonstrate acetylcholinesterase activity

\begin{tabular}{ccc}
\hline Age of Explantation & Foregut & Hindgut \\
\hline E9 & $2 / 4$ & $1 / 5$ \\
E10 & $5 / 10$ & $3 / 6$ \\
E11 & $19 / 22^{a}$ & $6 / 12^{b}$ \\
\hline
\end{tabular}

${ }^{a}$ Differs from the $50 \%$ of foregut cultures containing neurons that demonstrate acetylcholinesterase activity at days $\mathrm{E} 9$ and E10. $p<0.01$ $\left(\chi^{2}\right)$.

${ }^{b}$ Differs from the $20 \%$ of hindgut cultures containing neurons that demonstrate acetylcholinesterase activity at day E9. $p<0.02\left(\chi^{2}\right)$.

TABLE III

Synthesis of $\left[{ }^{3} \mathrm{H}\right] \mathrm{ACh}$ by enteric cultures

\begin{tabular}{ccc}
\hline $\begin{array}{c}\text { Fetal Age of } \\
\text { Explantation }\end{array}$ & Femtomoles per culture $\pm \mathrm{SE}$ & $n$ \\
\hline 10 & $3.4 \pm 0.7$ & 23 \\
11 & $2.7 \pm 0.4$ & 22 \\
12 & $8.5 \pm 1.3$ & 44 \\
14 & 1.8 & 14 \\
\hline
\end{tabular}

from vagal neural crest and migrate proximodistally within the gut wall during development. This hypothesis relates neuronal phenotypic expression to the migration of primordia and assumes that the reason that neurons are evident in proximal regions of the bowel before they can be discerned in distal regions is that the precursor cells reach the proximal gut first. Our data, however, do not support this view. We have found precursor cells in the most distal region of the gut at day E9, as early as we were able to detect precursors in the more proximal gut. Early precursors in the terminal bowel may be of sacral origin (LeDouarin and Teillet, 1973; LeDouarin, 1980). In any case, it seems likely that the proximodistal gradient in neuronal phenotypic expression is related to other factors, such as a gradient in maturation of the gut wall, rather than the migration of neuronal precursor cells down the extent of the bowel. 


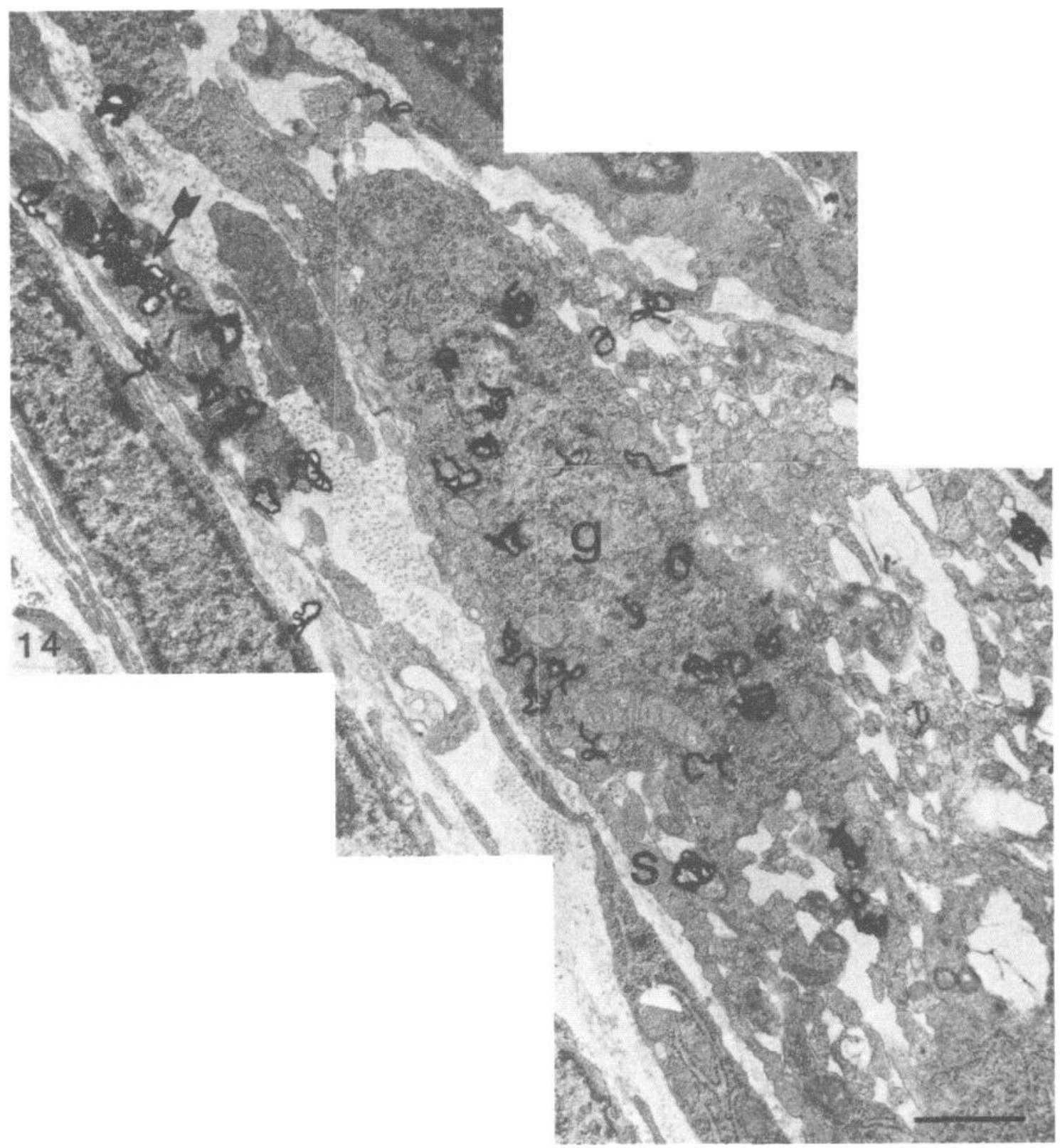

Figure 14. A montage of electron microscope radioautographs of a ganglion in an explant of fetal mouse gut removed at day E11, grown for 2 weeks in organotypic tissue culture, and incubated with $5-\left[{ }^{3} \mathrm{H}\right] \mathrm{HT}$. Labeling is found over neurites (arrow) as well as over a primitive appearing cell body of a neuron $(g)$ in the cultured ganglion. Cultured neural tissue has maintained its natural sheath of supporting cells $(s)$ and collagen is excluded from the enteric ganglion. Marker bar, $1.0 \mu \mathrm{m}$.

Although the first precursors of enteric neurons reach the developing mouse intestine as early as day E9, our culture experiments do not resolve definitively the issue of whether there is a continued inward migration of precursor cells after the early neuronal primordia arrive in the gut and, if so, for how long. Our observations, however, are consistent with the view that additional neuronal precursor cells continue to invade the bowel after day E9. A greater proportion of explants of fetal gut removed on day E11 (still prior to the appearance of recognizable neuritic elements in situ) develop neurons in organotypic tissue cultures than do explants removed on day E9 or E10. Although this might be due to enhanced survival of more mature precursor cells in the older explants under culture conditions, it also might suggest that more neuronal precursor cells had invaded older explants.

One factor that must be considered in discussing the development of a portion of the peripheral, if not the central, nervous system is the persistence of cell division of mature appearing precursor cells. It has been shown, for example, that precursor cells that give rise to sympathetic neurons, in contrast to those that produce the catecholaminergic neurons of the CNS, continue to divide even after they have acquired the ability to synthesize, store, and take up their neurotransmitter (Rothman et al., 1978, 1980). Enteric neuroblasts in the fetal guinea pig intestine, moreover, have been observed in mitosis 
almost as late as the time of birth (Gershon et al., 1981). These dividing cells resemble mature neurons in appearance and are even contacted by terminal axonal varicosities. Multiplication of precursor cells by division thus continues long after these cells colonize the bowel and probably serves to expand the precursor pool. The proliferation of neuronal precursors might conceivably explain the phenomena of enhanced development of cholinergic and serotonergic neurons in cultures explanted at day E11 over that in cultures explanted on days E9 or E10. The older explants would contain more precursor cells at the time of explantation, although there is no reason to suspect that proliferation would halt in organotypic tissue cultures.

The vanguard of neuronal precursor cells that colonize the fetal bowel on days E9 and E10 does not appear to be restricted in subsequent development to a single lineage of enteric neuron. Cultures explanted from these early guts evidently can produce both cholinergic and serotonergic neurons. Cholinergic neuronal development is indicated by the ability of cultures to synthesize $\left[{ }^{3} \mathrm{H}\right]$ $\mathrm{ACh}$ from $\left[{ }^{3} \mathrm{H}\right]$ choline and by the staining of neurons and their processes by a procedure to demonstrate acetylcholinesterase. Although this latter technique is not entirely specific for cholinergic neurons, these neurons in the gut are all characterized by the enzyme (Schofield, 1968). Serotonergic neuronal development is indicated by the presence of neuronal cell bodies and neurites that specifically take up $5-\left[{ }^{3} \mathrm{H}\right] \mathrm{HT}$ and become radioautographically labeled by the amine. It thus appears that if neuronal precursors are present in segments of bowel at the time of explantation into culture, then both cholinergic and serotonergic neurons can be produced by cells of this precursor pool. These data suggest that the first precursor cells to colonize the gut constitute a multipotential population, capable of developing into more than one of the types of neuron that ultimately reside in the mature enteric nervous system. Not resolved, however, is the issue of whether individual precursor cells within that population are pluripotent.

In the development of the murine bowel in silu, we could detect no difference in the timing of the earliest appearance of cholinergic or serotonergic neuronal expression. In the chicken, by way of contrast, cholinergic enteric neuronal expression precedes that of 5-HT (Epstein et al., 1980; Gershon et al., 1980) and the manifestation of enteric serotonergic properties begins at either end of the bowel and progresses toward the middle (Gershon et al., 1980). Both cholinergic and serotonergic neurons, moreover, develop early in ontogeny of the mouse gut, long before the ingrowth of the enteric noradrenergic innervation. This pattern, where cholinergic and serotonergic neurons appear long before the ingrowth of the enteric noradrenergic innervation, has been found to hold true for mice, rabbits, and guinea pigs (Gershon and Thompson, 1973; Rothman et al., 1976; Gintzler et al., 1980; Gershon et al., 1981) as well as chicks (Epstein et al., 1980; Gershon et al., 1980). Substance Pcontaining enteric neurons, furthermore, do not appear in the mouse gut until 4 days after birth (Sundler et al., 1977), while substance P- and vasoactive intestinal polypeptide (VIP)-containing nerves both appear 2 days after birth in the duodenum and 6 days after birth in the stomach of the rat (Larsson, 1977). There thus appears to be a reproducible sequence in enteric neuronal phenotypic expression. Cholinergic and serotonergic neurons appear first, while the noradrenergic innervation appears much later, and at least some of the peptidergic neurons develop latest of all.

The late development of some of the enteric neurons is interesting. The evidence presented in the current study is consistent with the view that the colonization of the gut by progenitor cells from the neural crest is a relatively prolonged process and that the pool of neuronal progenitor cells is multipotential even if individual precursor cells are not. That such a multipotential precursor pool or pluripotential cells exist is supported by the sequential order of enteric neuronal development in many animals. It is unlikely that committed precursor cells could migrate into the gut late in development to give rise to neurons, such as those that contain substance $P$, but which do not develop their phenotype until after birth. The neural crest has long since disappeared by then and it would be difficult to guess where an extrinsic source of precursor cells might be. Organotypic tissue cultures prepared from fetal mouse gut explanted late in development (E18 to E19), moreover, have been found to contain neurons that store substance $\mathrm{P}$, enkephalin, somatostatin, and VIP (Schultzberg et al., 1978). The precursors of these enteric peptidergic neurons must be present in the late fetal gut, therefore, even if the peptidergic neurons themselves are not. In consequence, it seems that the diversity of enteric neuronal phenotypic expression must depend on more than one factor. Some predetermination of separate lineages of precursor cells may exist; however, there also may be an interaction of a limited number of types of precursor with the enteric microenvironment. If the gut maintains an uncommitted or plastic progenitor pool, as its long retained population of dividing neuroblasts suggests (Gershon et al., 1981), then a microenvironment that changes sequentially as a function of time in ontogeny would provide a background of changing interactions that could give rise to the observed sequential order of enteric neuronal development.

\section{References}

Allan, I. J., and D. F. Newgreen (1980) The origin and differentiation of enteric neurons of the intestine of the fowl embryo. Am. J. Anat. 157: 137-154.

Andrew, A. (1964) The origin of intramural ganglia. I. The early arrival of precursor cells in the presumptive gut of chick embryos. J. Anat. 98: 421-428.

Andrew, A. (1971) The origin of intramural ganglia. IV. The origin of enteric ganglia: A critical review and discussion of the present state of the problem. J. Anat. 108: 169-184.

Bornstein, M. B. (1973) Organotypic mammalian central and peripheral nervous tissue. In Tissue Culture Models and Applications, P. F. Kruse and M. K. Patterson, eds., pp. 8692, Academic Press, New York.

Bunge, R., M. Johnson, and C. D. Ross (1978) Nature and nurture in development of the autonomic neuron. Science 199: 1409-1416.

Cantino, D. (1970) A historical study of the nerve supply to the developing alimentary tract. Experientia 26: 766-767.

Cochard, P., M. Goldstein, and I. B. Black (1978) Ontogenetic 
appearance and disappearance of tyrosine hydroxylase and catecholamines in the rat embryo. Proc. Natl. Acad. Sci. U. S. A. 75: 2986-2990.

Cook, R. D., and E. R. Peterson (1974) The growth of smooth muscle and sympathetic ganglia in organotypic cultures. Light and electron microscopy. J. Neurol. Sci. 22: 25-38.

Coughlin, M. D. (1975) Early development of parasympathetic nerves in the mouse submandibular gland. Dev. Biol. 43: 123139.

Drakontides, A. B., and M. D. Gershon (1972) Studies of the interaction of 5-hydroxytryptamine $\left(5-\mathrm{H}^{\prime} \mathrm{T}\right)$ and the perivascular innervation of the guinea-pig caecum. Br. J. Pharmacol. 45: 417-434.

Dreyfus, C. F., M. B. Bornstein, and M. D. Gershon (1977a) Synthesis of serotonin by neurons of the myenteric plexus in situ and in organotypic tissue culture. Brain Res. 128: 125139.

Dreyfus, C. F., D. Sherman, and M. D. Gershon (1977b) Uptake of serotonin by intrinsic neurons of the myenteric plexus grown in organotypic tissue culture. Brain Res. 128: 109-123.

El-Badawi, A., and E. A. Schenk (1967) Histochemical methods for separate consecutive and simultaneous demonstration of acetylcholinesterase and norepinephrine in cryostat sections. J. Histochem. Cytochem. 15: 580-588.

Epstein, M. L., D. Sherman, and M. D. Gershon (1980) Development of serotonergic neurons in the chick duodenum. Dev. Biol. 77: 22-40.

Furness, J. B., and M. Costa (1980) Types of nerves in the enteric nervous system. Neuroscience 5: 1-20.

Gershon, M. D. (1981) 'The enteric nervous system. Annu. Rev. Neurosci. 4: 227-272.

Gershon, M. D., and R. E. Altman (1971) An analysis of the uptake of 5-hydroxytryptamine by the myenteric plexus of the small intestine of the guinea pig. J. Pharmacol. Exp. Ther. 179: 29-41.

Gershon, M. D., and G. M. Jonakait (1979) Uptake and release of 5-hydroxytryptamine by enteric 5-hydroxytryptaminergic neurons: Effects of fluoxetine (Lilly 110140) and chlorimipramine. Br. J. Pharmacol. 66: 7-9.

Gershon, M. D., and L. L. Ross (1966) Radioisotopic studies of the binding exchange and distribution of 5-hydroxytryptamine synthesized from its radioactive precursor. J. Physiol. (Lond.) 186: 451-476.

Gershon, M. D., and E. B. Thompson (1973) The maturation of neuromuscular function in a multiply innervated structure Development of the longitudinal smooth muscle of the foetal mammalian gut and its cholinergic excitatory, adrenergic inhibitory innervation. J. Physiol. (Lond.) 234: 257-278.

Gershon, M. D., R. G. Robinson, and L. L. Ross (1976) Serotonin accumulation in the guinea pig's myenteric plexus: Ion dependence, structure activity relationship, and the effect of drugs. J. Pharmacol. Exp. Ther. 198: 548-561.

Gershon, M. D., M. L. Epstein, and L. Hegstrand (1980) Colonization of the chick gut by progenitors of enteric serotonergic neurons: Distribution, differentiation and maturation within the gut. Dev. Biol. 77: 41-51.

Gershon, M. D., D. Sherman, and A. R. Gintzler (1981) An ultrastructural analysis of the developing enteric nervous system of the guinea pig small intestine. J. Neurocytol. 10 . 271-296.

Gintzler, A. R., T. P. Rothman, and M. D. Gershon (1980) Ontogeny of opiate mechanisms in relation to the sequential development of neurons known to be components of the guinea pig's enteric nervous system. Brain Res. 189: 31-48.

Haubrich, D. R., and T. J. Chippendale (1977) Regulation of acetylcholine synthesis in nervous tissue. Life Sci. 20: 14651478.

Kopriwa, B. M. (1975) A comparison of various procedures for fine grain development in electron microscopic radioautog. raphy. Histochemistry 44: 201-224.

Landis, S. C., and D. Keefe (1980) Development of cholinergic sympathetic innervation of eccrine sweat glands in rat footpad. Soc. Neurosci. Abstr. 6: 379.

Larsson, L. -I. (1977) Ultrastructural localization of a new neuronal peptide (VIP). Histochemistry $54: 173-176$.

LeDouarin, N. M. (1980) The ontogeny of the neural crest in avian embryo chimeras. Nature 286: 663-669.

LeDouarin, N. M., and M. A. Teillet (1973) The migration of neural crest cells to the wall of the digestive tract in the avian embryo. J. Embryol. Exp. Morphol. 30: 31-48.

Patterson, P. H. (1978) Environmental determination of autonomic neurotransmitter functions. Annu. Rev. Neurosci. 1: $1-17$.

Pert, C. B., and S. H. Snyder (1974) High affinity transport of choline into the myenteric plexus of guinea-pig intestine. $J$. Pharmacol. Exp. Ther. 191: 102-108.

Rothman, T. P., L. L. Ross, and M. D. Gershon (1976) Separately developing axonal uptake of 5-hydroxytryptamine and norepinephrine in the fetal ileum of the rabbit. Brain Res. 115: 437-456

Rothman, T. P., M. D. Gershon, and H. Holtzer (1978) The relationship of cell division to the acquisition of adrenergic characteristics by developing sympathetic ganglia cell precursors. Dev. Biol. 65: 322-341.

Rothman, T. P., L. A. Specht, M. D. Gershon, T. H. Joh, G. Teitelman, V. M. Pickel, and D. J. Reis (1980) Catecholamine biosynthetic enzymes are expressed in replicating cells of the peripheral but not central nervous system. Proc. Natl. Acad. Sci. U. S. A. 77: 6221-6225.

Schofield, G. C. (1968) Anatomy of muscular and neural tissue in the alimentary canal. In Handbook of Physiology, C. F. Code, ed., Vol. IV, pp. 1579-1627, Williams and Wilkins, Baltimore.

Schultzberg, M., C. F. Dreyfus, M. D. Gershon, T. Hökfelt, R. P. Elde, G. Nilsson, S. Said, and M. Goldstein (1978) VIP-, enkephalin-, substance $\mathrm{P}$ - and somatostatin-like immunoreactivity in neurons intrinsic to the intestine: Immunohistochemical evidence from organotypic tissue cultures. Brain Res. 155: 239-248.

Steinbusch, H. W. M., and A. J. Verhofstad (1979) Immunofluorescent staining of serotonin in the central nervous system. In Advances in Pharmacology and Therapeutics. Vol. 2: Neurotransmitters, P. Simon, ed., pp. 151-160, Pergamon Press, Oxford.

Steinbusch, H. W. M., D. Van Der Kooy, A. A. J. Verhofstad, and A. Pelligrino (1980) Serotonergic and non-serotonergic projections from the nucleus raphe dorsalis to the caudateputamen complex in the rat, studied by a combined immunofluorescence and fluorescent retrograde axonal labeling technique. Neurosci. Lett. 9: 137-142.

Sundler, F., R. Håkanson, L. -I. Larsson, E. Brodin, and G. Nilsson (1977) Substance $P$ in the gut. An immunochemical and immunohistochemical study of its distribution and development. In Substance P, U. S. Von Euler and B. Pernow, eds., pp. 59-65, Raven Press, New York.

Teitelman, G., T. H. Joh, and D. J. Reis (1978) Transient expression of a noradrenergic phenotype in cells of the rat embryonic gut. Brain Res. 158: 229-234.

Teitelman, G., M. D. Gershon, T. P. Rothman, T. H. Joh, and D. J. Reis (1981) Proliferation and distribution of cells that transiently express a catecholaminergic phenotype during development in mice and rats. Dev. Biol. 86: 348-355.

Tennyson, V. M. (1970) The fine structure of the axon and growth cone of the dorsal root neuroblast of the rabbit embryo. J. Cell Biol. 44: 62-79.

Tennyson, V. M., and M. Brzin (1970) The appearance of 
acetylcholinesterase in the dorsal root neuroblast of the rabbit embryo. J. Cell Biol. 46: 64-80.

Thoa, N. B., D. Eccelston, and J. Axelrod (1969) The accumulation of $\mathrm{C}^{14}$-serotonin in the guinea-pig vas deferens. J. Pharmacol. Exp. Ther. 169: 68-73.

Webster, W. (1973) Fmbryogenesis of the enteric ganglia in normal mice and in mice that develop congenital aganglionic megacolon. J. Embryol. Exp. Morphol. 30: 573-585.

Wong, D. T., J. S. Horng, F. P. Byinaster, K. L. Hauser, and B. B. Molloy (1974) A selective inhibitor of serotonin uptake: Lilly 110140, 3-(b-trifluoromethylphenoxy)- $N$-methyl3-phenylpropylamine. Life Sci. 15: 471-479. 